\title{
KELAHIRAN BARU DI DALAM KRISTUS SEBAGAI TITIK AWAL PENDIDIKAN KARAKTER UNGGUL
}

\author{
David Eko Setiawan \\ Sekolah Tinggi Teologi Tawangmangu \\ Tromol Pos I, Kalisoro RT.1, RW.4, Tawangmangu, Karanganyar \\ Email: davidekosetiawan14217@gmail.com
}

\begin{abstract}
David Eko Setiawan, Superior character education is a conscious and planned effort with the aim of internalizing moral and moral values, so that it can be realized in the application of good attitudes and behavior. To achieve these goals, it is necessary to think of an important event that must occur in human life. The event is called the new birth. New birth is a spiritual event that can only be done by God through the Holy Spirit to people who believe in the preaching of the gospel. When the event occurs, God will give him a new life. At that time the old nature was replaced with a new nature so that believers could reveal a new life. The correlation of the new birth with superior character education is through new birth individuals experience very significant changes. These changes touch aspects of the mind, feeling, and will so that one can have superior qualities in him. This is the key to radical change in a person so that eventually he can have a superior character.
\end{abstract}

Keywords: A New birth, Superior Character, Superior Character Education

\begin{abstract}
Abstrak: David Eko Setiawan, Pendidikan karakter unggul adalah usaha sadar dan terencana dengan tujuan menginternalisasikan nilai moral dan akhlak, sehingga hal itu dapat diwujudkan dalam penerapan sikap dan perilaku yang baik. Untuk mencapai tujuan tersebut maka perlu dipikirkan sebuah peristiwa terpenting yang harus terjadi dalam kehidupan manusia. Peristiwa itu disebut kelahiran baru. Kelahiran baru merupakan peristiwa spiritual yang hanya dapat dikerjakan oleh Allah melalui Roh Kudus kepada manusia yang percaya kepada pemberitaan Injil. Ketika peristiwa tersebut terjadi, maka Allah akan memberikan kehidupan baru kepadanya. Saat itu juga kodrat lama digantikan dengan kodrat yang baru sehingga orang percaya dapat mengungkapkan hidup yang baru. Korelasi kelahiran baru dengan pendidikan karakter unggul adalah melalui kelahiran baru individu mengalami perubahan yang sangat signifikan. Perubahan tersebut menyentuh aspek pikiran, perasaan, dan kehendak sehingga seseorang dapat memiliki sifat-sifat unggul pada dirinya. Hal ini menjadi kunci perubahan yang radikal di dalam diri seseorang sehingga akhirnya dia dapat memiliki karakter unggul.
\end{abstract}

Kata Kunci: Kelahiran Baru, Karakter Unggul, Pendidikan Karakter Unggul

\section{PENDAHULUAN}

Krisis karakter pada sebagian besar manusia akhir-akhir ini telah memunculkan harapan besar hadirnya pribadi-pribadi yang berkarakter unggul. Karakter unggul yang dimaksud adalah sifat-sifat yang melekat pada diri seseorang yang telah mengalami perubahan dan berdampak positif bagi orang tersebut. Dampak itu secara nyata memengaruhi relasinya dengan Allah, sesama, dan dunia. Namun demikian, ada suatu hal yang perlu dipertanyakan, bagaimanakah seseorang dapat memiliki karakter unggul itu? Pendidikan karakter unggul pada diri seseorang dapat dilakukan dengan berbagai cara, misalnya melalui training pengembangan sumber daya manusia, pembinaan-pembinaan rohani dan lain-lain. Tetapi masih didapati fakta adanya kegagalan dalam usahausaha itu sehingga perlu dicari faktor penyebabnya. Dalam penelitiannya, Telaumbanua (2018) menemukan bahwa guru berperan penting dalam pendidikan karakter. Salah satu tugas guru menurut Telaumbanua adalah membimbing murid mengalami pertobatan dan iman (lahir baru). Sementara menurut Wenas dan Darmawan (2017) peran guru dan orang tua sangat penting dalam membimbing anak-anak memperoleh pengetahuan akan karya keselamatan yang Allah sediakan di dalam Yesus Kristus, setelah itu akan terjadi proses menjadikan mereka taat dan setia, sebagai salah satu karakter Kristen. Salah satu 
cara untuk mendidik anak memiliki karakter yang baik, menurut Emiyati (2018) adalah dengan memberikan disiplin sehingga memiliki ketaatan, serta mampu memilih dan melakukan hal-hal yang benar. Hanya pelaksanaan disiplin merupakan tindakan yang menurut penulis dilakukan pasca anak-anak menerima Yesus Kristus. Oleh sebab itu, perlu diteliti kaitan antara kelahiran baru dalam Kristus dengan pendidikan karakter.

Penelitian lain yang relevan dengan penelitian ini adalah penelitian yang dilakukan Rifai (2012) yang membahas tentang pendidikan Kristen dalam membangun karakter remaja di sekolah menengah. Penelitian Rifai lebih mengedepankan peran pendidikan agama Kristen secara formal untuk membangun karakter anak remaja di sekolah menengah. Yang sama dengan penelitian tersebut ada-lah sama-sama berfokus pada pendidikan karakter. Perbedaan antara penelitian ini dengan penelitian yang dilakukan oleh Rifai adalah pada subjeknya. Penelitian Rifai pada anak-anak remaja Kristen, sedangkan penelitian ini berfokus kepada seseorang yang mengalami kelahiran baru. Perbedaan lainnya adalah Rifai meneliti peran pendidikan Kristen secara formal bagi pembentukan karakter, sedangkan penelitian ini menekankan peran kelahiran baru dalam pendidikan karakter unggul. Penelitian lain yang relevan adalah penelitian Hartono (2014). Namun demikian Hartono menyoroti pembentukan karakter Kristen pada keluarga Kristen tanpa membahas peran kelahiran baru bagi terbentuknya karakter tersebut. Kedua penelitian tersebut telah dipublikasikan pada jurnal dan relevan dengan penelitian ini.

Penelitian ini bertujuan untuk menjelaskan tentang kelahiran baru sebagai titik awal pendidikan karakter unggul pada diri seseorang. Penulis berpendapat bahwa kelahiran baru merupakan titik awal dalam pendidikan karakter unggul. Tanpa kelahiran baru maka harapan memiliki karakter unggul menjadi sia-sia. Pendapat penulis ini berdasarkan II Korintus 5:17 "Jadi siapa yang ada di dalam Kristus, ia adalah ciptaan baru: yang lama sudah berlalu, sesungguhnya yang baru sudah datang”. Seseorang yang ada di dalam Kristus dinyatakan jelas oleh Firman Allah sebagai ciptaan baru, di mana tabiat lamanya telah berlalu dan tabiat baru sudah datang. Tabiat baru ini oleh Roh Kudus akan terus menerus diperbaharui sehingga orang percaya memiliki karakter unggul di dalam Kristus (Kol. 3:7-16).

Rumusan masalah dalam penelitian ini adalah bagaimana kaitan kelahiran baru dalam Kristus dengan pendidikan karakter unggul? Sedangkan tujuan penelitian ini adalah memaparkan kaitan kelahiran baru dalam Kristus dengan pendidikan karakter unggul.

\section{METODE}

Penelitian ini menggunakan metode studi literatur. Peneliti berusaha menjawab permasalahan penelitian dengan mencari sumber-sumber literatur yang berkorelasi dengan masalah penelitian. Sumber-sumber tersebut adalah buku-buku teks dan juga jurnal-jurnal ilmiah. Pendekatan tematis digunakan untuk memahami korelasi kelahiran baru di dalam Kristus dengan pendidikan karakter unggul. Kemudian peneliti menganalisis sumber-sumber yang terkait dengan menggunakan analisis dokumen/analisis isi. Teknik analisis tersebut merupakan kajian yang menitikberatkan pada tafsiran/ pemahaman terhadap bahan tertulis sesuai dengan konteks untuk memperoleh jawaban atas permasalahan yang diteliti. Beberapa sumber pustaka yang digunakan dalam penelitian ini adalah buku-buku karya Paul Enns, Donald Guthrie, Charles Ryrie, dan Dharma Kesuma. Peneliti juga mencermati beberapa teks Alkitab Perjanjian Baru yang membahas tentang kelahiran baru. Selanjutnya, peneliti mendeskripsikan hasil analisis tersebut sehingga menjadi uraian yang terperinci dan mendalam.

\section{HASIL DAN PEMBAHASAN}

\section{Pengertian Kelahiran Baru di dalam Kristus}

Kelahiran baru memiliki arti yang sangat penting untuk dipahami dan menghasilkan sebuah konsep yang tepat. Bagian ini menjelaskan tentang 
pengertian kelahiran baru berdasarkan teks Alkitab dan para pakar, supaya banyaknya pandangan tentang kelahiran baru tidak mengaburkan konsep tentang kelahiran baru.

\section{Pengertian Kelahiran Berdasarkan Teks Alkitab}

Alkitab membahas tentang kelahiran baru dalam beberapa bagian teksnya, antara lain:

\section{Yohanes 3: 5-7}

Teks Yohanes 3:5-7 dalam Alkitab versi Terjemahan Baru (TB) dituliskan demikian:

Aku berkata kepadamu, sesungguhnya jika seorang tidak dilahirkan dari air dan Roh, ia tidak dapat masuk ke dalam Kerajaan Allah. Apa yang dilahirkan dari daging, adalah daging, dan apa yang dilahirkan dari Roh, adalah roh. Janganlah engkau heran, karena Aku berkata kepadamu: Kamu harus dilahirkan kembali.

Sedangkan dalam Alkitab versi Interlinear Greek New Testament (IGNT) dituliskan demikian:

$\alpha \pi \varepsilon \kappa \rho \imath \theta \eta$ o ı

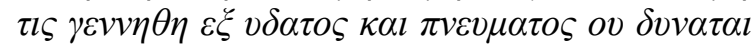

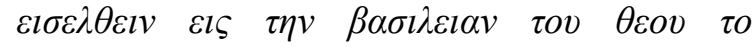

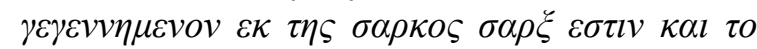

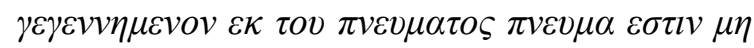

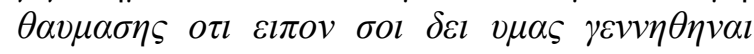
$\alpha v \omega \theta \varepsilon v$

Teks di atas adalah sebagian dialog antara Yesus dengan Nikodemus. Yesus mengatakan dengan tegas bahwa Nikodemus tidak dapat masuk ke dalam Kerajaan Allah bila tidak dilahirkan kembali. Yesus menjelaskan bahwa kelahiran kembali atau kelahiran baru (Yunani: $\alpha v \omega \theta \varepsilon v$-Anothen) merupakan suatu syarat mutlak agar seseorang dapat masuk ke dalam Kerajaan Allah.

Kelahiran baru menjadikan manusia sebagai ciptaan baru yang mencari, mendapatkan, dan mengikuti Kristus. Yohanes 1:13 dan 3:3, 5, 7 mencatat frasa kelahiran baru dalam bentuk-bentuk aorist tense, yaitu suatu hal yang sekali saja dilakukan tetapi memiliki dampak untuk seterusnya, seperti dalam Yohanes 2:29; 3:9; 4:7; 5:1, 4, 18. Kelahiran baru merupakan suatu tindakan Roh Kudus atas kodrat manusia sekali sepanjang hidup dan memberi dam- pak perubahan dalam seluruh kehidupan pribadi seseorang.

1 Yohanes 2:29; 3:9; 4:7; 5:4; 5:18.

Kelahiran baru merupakan proses rohani yang dilakukan oleh Allah pada seseorang di dalam Kristus yang berdampak pada hubungannya dengan Allah, sesama manusia, dan dunia di dalam kehidupan sehari-hari. Pertama, kelahiran baru memberikan identitas baru, yaitu sebagai anak-anak Allah. Yohanes mengatakan bahwa orang-orang percaya adalah orang yang lahir dari Allah (1Yoh. 2:29; 3:9; 4:7; 5:4; 5:18). Kelahiran baru mendamaikan manusia dengan Allah melalui penebusan Kristus di atas kayu salib.

Kedua, orang yang lahir dari Allah memiliki suatu daya untuk mengasihi dan tidak berbuat dosa. Yohanes mengatakan bahwa setiap orang yang lahir dari Allah tidak akan terus-menerus berbuat dosa (1 Yoh. 3:9; 5:18), hal ini menunjukkan bahwa melalui kelahiran baru, Allah memberikan suatu natur baru sebagai ciptaan baru yang sekaligus memiliki suatu kemampuan untuk memilih berbuat benar dan mengasihi orang lain, bahkan lebih dari itu kelahiran baru membuat orang mengenal Allah (1 Yoh. 3:9$10 ; 4: 7)$.

Ketiga, kelahiran baru memberikan kemampuan untuk mengalahkan dunia melalui iman, yaitu kemampuan untuk melakukan segala perintah Allah (1 Yoh. 5:4). Yohanes mengatakan bahwa orang yang lahir dari Allah adalah orang yang mengasihi Allah dan sesama manusia. Kasih terhadap sesama manusia terwujud dengan mengasihi Allah dan melakukan segala perintah-Nya. Segala perintah Allah itu tidak berat, karena Allah memberikan kemampuan untuk mengalahkan dunia.

\section{Petrus 1:21-23}

Kelahiran baru merupakan karya Allah di dalam Yesus melalui penebusan yang memperbaharui orang percaya sehingga dia dapat lebih mengembangkan karakternya. Teks 1 Petrus 1:21-23 menyampaikan bahwa oleh karena Yesus, manusia te- 
lah dilahirkan kembali bukan dari benih yang fana, melainkan benih yang tidak fana oleh firman Allah yang hidup dan kekal, sehingga manusia dapat percaya kepada Allah serta memiliki iman dan pengharapan yang tertuju kepada Allah.

Petrus mengaitkan tindakan kasih persaudaraan yang tulus ikhlas pada jemaat penerima suratnya dengan karya penebusan Kristus (1 Pet. 1:1820), sehingga jemaat harus lebih sungguh-sungguh dalam mengamalkan kasih persaudaraan karena mereka telah dilahirkan kembali.

\section{Pengertian Kelahiran Baru di dalam Kristus dari beberapa pakar Alkitab}

Beberapa pakar Alkitab telah berusaha menyelidiki tentang pengertian dan makna kelahiran baru pada orang percaya. Berbagai pandangan mereka perlu dipertimbangkan agar lebih memperjelas arti dari kelahiran baru.

Enns menjelaskan kelahiran baru dengan istilah regenerasi. Enns (2003, p. 421) mengartikan kelahiran baru sebagai suatu kelahiran dari atas, yaitu dari Allah. Kelahiran baru merupakan kelahiran spiritual yang dilakukan oleh Allah melalui Roh Kudus sehingga orang percaya mengalami hidup baru saat dia menerima Yesus sebagai Tuhan dan Juruselamat. Orang percaya yang dilahirkan baru berarti dia menerima natur ilahi (2 Pet. 1:4), jati diri yang baru (Ef. 4:24), suatu kapasitas untuk hidup benar dan menjadi ciptaan baru (2 Kor. 5:17). Orang percaya juga menerima pikiran yang baru sehingga dapat mengenal Allah (1 Kor. 2:16), hati yang baru sehingga dapat mengasihi Allah (Rm. 5: 5), dan suatu kehendak baru (Rm. 6:13) sehingga dapat menaati Allah.

Milne (1996, p. 258) menjelaskan kelahiran baru sebagai saat dan cara orang percaya memasuki persatuan dengan Kristus, suatu perubahan serentak dari kematian spiritual menuju kehidupan spiritual, sebagai suatu kebangkitan spritual (Ef. 2:1-5). Milne menjelaskan bahwa kelahiran baru merupakan peristiwa yang terjadi sekali untuk selama-lamanya pada permulaan kehidupan Kristen. Kelahiran baru meru- pakan tindakan Allah dalam memberikan hidup baru sehingga orang percaya menerima watak rohani baru yang diungkapkan dalam perhatian dan minat-minat baru yaitu kepedulian akan firman Allah, umat Allah, pelayanan kepada Allah, dan kesanggupan untuk menolak dosa.

Guthrie (1995, p. 229) menjelaskan kelahiran baru berdasarkan beberapa teks di dalam Perjanjian Baru yaitu Yohanes 3, 1 Yohanes 2:29; 3:9; 4:7; 5:4; 5:18, Titus 3:5, 1 Petrus 1:23, dan Yakobus 1:8. Guthrie menjelaskan pengertian kelahiran baru sebagai pertukaran kodrat lama seseorang dengan kodrat yang baru, penerimaan suatu asal usul yang baru, dan perjalanan masuk kepada hubungan yang baru dengan Allah (Yoh. 3). Kelahiran baru akan diikuti dengan dampak-dampak rohani tertentu pada orang percaya yaitu orang percaya akan berhenti dari berbuat dosa (1 Yoh. 3:9; 5:18), dapat mengenal Allah (1 Yoh. 4:7), dan dapat mengalahkan dunia melalui imannya (1 Yoh. 5:4). Guthrie kemudian menyimpulkan bahwa kelahiran baru pada dasarnya akan menghasilkan pembaharuan cara hidup pada diri orang percaya (Tit. 3:5, I Pet. 1:23 dan Yak. 1:18). Ryrie (1999, p. 86) menjelaskan arti kelahiran baru sebagai pekerjaan Allah yang memberikan kehidupan baru kepada orang percaya. Kelahiran baru dilakukan oleh Allah (Yoh. 1:3), menurut kehendakNya (Yak. 1:8) oleh Roh Kudus (Yoh. 3: 5) ketika seseorang percaya kepada Injil yang dinyatakan oleh firman-Nya (1 Pet. 1:23). Kelahiran baru akan membuahkan kehidupan yang baru, yaitu kebenaran, tidak berbuat dosa, saling mengasihi, dan mengalahkan dunia (1 Yoh. 2:29; 3:9; 4:7; 5:1,4 dan 18). Hadiwijono (1995, p. 398) menjelaskan bahwa kelahiran baru adalah karya langsung Allah melalui Roh Kudus, untuk memberikan kehidupan yang baru kepada manusia yang secara rohani telah mati, sehingga orang yang percaya dapat mengungkapkan kehidupannya yang baru.

Berdasarkan pandangan para pakar di atas maka penulis menyimpulkan bahwa kelahiran baru merupakan peristiwa yang terjadi ketika seseorang menerima Yesus Kristus sebagai Tuhan dan selamat 
secara pribadi. Peristiwa ini sangatlah penting bagi orang percaya. Karena melaluinya orang percaya menjadi ciptaan baru dan menerima hidup baru yang diungkapkan dalam perhatian dan minat-minat baru. Selain itu, orang percaya juga menghasilkan pembaharuan cara hidup yang akan berdampak bagi dirinya sendiri dan lingkungannya.

\section{Konklusi tentang Pengertian Kelahiran Baru di dalam Kristus}

Kelahiran baru merupakan istilah Alkitab yang perlu untuk mendapatkan penjelasan secara konkrit. Berdasarkan beberapa teks dalam Alkitab dan pandangan para pakar Alkitab maka konsep tentang kelahiran baru dapat disimpulkan sebagai berikut:

\section{Pengertian Istilah Kelahiran Baru}

Kelahiran baru adalah suatu peristiwa rohani di mana Allah memberikan kehidupan baru kepada diri seseorang yang mengambil keputusan untuk percaya kepada Yesus dan menerima-Nya sebagai Tuhan dan Juruselamat pribadi, sehingga dia menggalami persatuan dengan-Nya. Kelahiran baru merupakan syarat mutlak yang tidak dapat ditawar, sehingga orang yang tidak dilahirkan baru tidak dapat masuk ke dalam Kerajaan Allah. Kelahiran baru merupakan peristiwa spiritual yang hanya dapat dikerjakan oleh Allah melalui Roh Kudus kepada manusia yang percaya kepada pemberitaan Injil. Kelahiran baru membuat seseorang memiliki kodrat dan asal-usul yang baru, serta perjalanan masuk kepada hubungan yang baru dengan Allah, sehingga orang percaya dapat mengungkapkan hidup yang baru.

\section{Hasil-hasil Kelahiran Baru}

Hasil-hasil kelahiran baru adalah:

\section{Masuk ke dalam Kerajaan Allah (Yohanes 3:3;} 3:5)

Yesus menyatakan bahwa tanpa kelahiran baru maka tidak mungkin seseorang masuk ke dalam Kerajaan Allah. Kurniawan (2018, p. 3) menjelaskan berkenaan dengan pernyataan Yesus di atas, bahwa untuk masuk ke dalam Kerajaan Allah merupakan anugerah Allah yang terjadi dalam peristiwa khusus, yaitu kelahiran baru. Piper (2008, p.63) menegaskan bahwa anugerah Allah melalui kelahiran baru merupakan tindakan yang secara khusus Allah lakukan sendiri.

\section{Identitas Baru (Yohanes 1:12)}

Ketika seseorang dilahirkan baru maka seketika itu dia memiliki identitas baru yaitu sebagai anak-anak Allah. Guthrie (2008, p. 228) menjelaskan bahwa wawasan tentang kelahiran baru pertama kali diisyaratkan di dalam Yohanes 1:12, di mana saat itulah orang percaya menerima kuasa untuk menjadi anak-anak Allah. Identitas baru tersebut menjadikan orang percaya memiliki relasi yang baru dengan Allah.

\section{Memiliki Hidup Baru}

Kelahiran baru menghasilkan hidup yang baru. Saat orang percaya mengalami kelahiran baru maka dia akan memiliki minat-minat yang baru pula, antara lain: kepedulian akan firman Allah, umat Allah, pelayanan kepada Allah dan kesanggupan untuk menolak dosa. Kesemuanya itu disebabkan adanya perubahan oleh karena karya Roh Kudus pada watak orang tersebut. Wijaya (2016, p. 128) menjelaskan bahwa melalui kuasa Roh Kudus, orang percaya akan terus menerus diperbaharui sehingga menghasilkan kehidupan baru.

\section{Pendidikan Karakter Unggul}

Pendidikan karakter unggul pada seseorang telah menjadi kebutuhan yang mendesak pada masa kini. Hal ini didasari oleh semakin jarangnya karakter unggul di tengah-tengah masyarakat. Maka dari itu pembahasan tentang pendidikan karakter unggul perlu diketengahkan pada bagian berikut.

\section{Pengertian Karakter}

Karakter adalah watak, tabiat atau sifat-sifat yang menjadi ciri khas dari tiap individu sehingga 
melaluinya cara berpikir dan perilakunya dapat dibedakan dengan individu lainnya. Suyanto dan Muslich (2011, p.70) berpendapat bahwa karakter merupakan ciri khas seseorang dalam berpikir dan berperilaku di lingkungan keluarga, masyarakat, dan negara, sedangkan Poerwadarminta (1998, p. 389) dan Kamisa (1997, p.281) menjelaskan karakter sebagai budi pekerti atau sifat-sifat kejiwaan yang membedakan antar manusia. Dictionary of Pastoral Care and Counseling (1990, p. 137) dan Gulo (1982, p. 29) menguraikan perbedaan antarmanusia dalam karakternya disebabkan oleh elemen-elemen yang membentuk kepribadian seseorang, sebagai kumpulan kualitas pada diri seseorang yang dapat dinilai berdasarkan standar etis dan moral tertentu.

\section{Karakter Unggul}

Karakter unggul adalah kumpulan sifat-sifat yaitu rangkaian sikap (attitudes), perilaku (behaviors), motivasi (motivations), dan keterampilan (skills) yang melekat pada diri seseorang yang berdampak positif bagi orang tersebut dalam relasinya dengan Allah, diri sendiri dan sesamanya. Alkitab mencatat beberapa karakter unggul, yang secara konkret ditunjukkan oleh Rasul Paulus dalam surat Galatia 5: 22-23, yaitu: kasih, sukacita, damai sejahtera, kesabaran, kemurahan, kebaikan, kesetiaan, kelemah lembutan dan penguasaan diri. Keunggulan dari beberapa jenis karakter itu ditunjukkan dengan pernyataan bahwa "tidak ada hukum yang menentang halhal itu" (ayat 23).

\section{Pengertian Pendidikan Karakter}

Kesuma (2013, p.4) menyampaikan bahwa pendidikan karakter saat ini semakin diterima luas oleh masyarakat. Hal ini seiring dengan semakin mendesaknya kebutuhan akan karakter unggul di dalam masyarakat. Pendidikan karakter adalah usaha sadar dan terencana dengan tujuan menginternalisasikan nilai moral dan akhlak, sehingga hal itu dapat diwujudkan dalam penerapan sikap dan perilaku yang baik. Gaffar (2010, p.4) menguraikan bahwa pendidikan karakter merupakan sebuah proses meng- ubah nilai-nilai dalam hidup manusia untuk menumbuh kembangkan kepribadian seseorang menjadi sebuah perilaku. Lickona (1991) memperjelas uraian Gaffar mengenai nilai-nilai hidup dengan istilah etika inti yang harus dipahami, diperhatikan, dan dilakukan, sebagai suatu usaha yang dilakukan secara sadar.

\section{Korelasi Kelahiran Baru di dalam Kristus dengan Pendidikan Karakter Unggul}

Pendidikan karakter unggul adalah usaha sadar dan terencana dengan tujuan menginternalisasikan nilai moral dan akhlak, sehingga hal itu dapat diwujudkan dalam penerapan sikap dan perilaku yang baik. Usaha tersebut dapat dilakukan dalam lingkungan formal dan informal. Secara formal, usaha tersebut dapat melibatkan lembaga-lembaga pendidikan yang berbasis kurikulum tertentu yang mengacu pada tujuan terciptanya karakter unggul pada peserta didik. Kemudian secara informal usaha tersebut dapat dilakukan dalam pembinaan di dalam lingkungan keluarga dan masyarakat. Hal ini dapat melibatkan peran serta orang tua dan tokoh-tokoh masyarakat terhadap pembinaan karakter bagi anggota keluarga dan masyarakatnya.

Namun demikian perlu diperhatikan bahwa segala usaha itu seharusnya beranjak dari suatu peristiwa penting yang harus terjadi pada diri seseorang. Peristiwa tersebut adalah kelahiran baru. Melalui kelahiran baru individu mengalami perubahan yang sangat signifikan. Paul Enns (2003, p.21) menegaskan bahwa perubahan tersebut menyentuh aspek pikiran, perasaan, dan kehendak sehingga seseorang dapat memiliki sifat-sifat unggul pada dirinya. Hal ini menjadi kunci perubahan yang radikal di dalam diri seseorang untuk memiliki karakter unggul. Brownlee (2006, p.130) menunjukkan korelasi antara kelahiran baru dengan perubahan radikal pada seseorang sebagai berikut:

Kita menanggalkan keadaan kita yang lama supaya kita "dibaharui di dalam roh dan pikiran (kita), dan mengenakan manusia baru, yang telah diciptakan menurut kehendak Allah di dalam kebenaran dan kekudusan yang sesungguh- 
nya. Perubahan diri kita ialah perubahan radikal. Perubahan ini bukan perbaikan perbaikan beberapa hal saja, bukan peningkatan kebaikan dan kepandian, bukan pendidikan, melainkan dasar dari diri kita dan tabiat kita diubah dan diperbaharui. Karena itu istilah "kebangkitan manusia baru atau "kelahiran baru" patut dipakai untuk menekankan sifat radikal dari perubahan ini”.

Berdasarkan pernyataan Brownlee di atas maka tepatlah untuk dikatakan bahwa kelahiran baru merupakan titik awal dari sebuah perubahan. Dia mengatakan bahwa realitas perubahan itu akan berlangsung terus menerus setiap hari hingga seseorang serupa dengan Kristus. Di sinilah titik awal usaha untuk menginternalisasikan nilai-nilai moral dan akhlak sehingga terwujud dalam penerapan sikap dan perilaku yang baik. Tanpa kelahiran baru maka manusia tetap seperti keadaanya yang semula yaitu berdosa. Kitab Efesus menjelaskan keadaan tersebut sebagai berikut:

Kamu dahulu sudah mati karena pelanggaranpelanggaran dan dosa-dosamu.Kamu hidup di dalamnya, karena kamu mengikuti jalan dunia ini, karena kamu menaati penguasa kerajaan angkasa, yaitu roh yang sekarang sedang bekerja di antara orang-orang durhaka. Sebenarnya dahulu kami semua juga terhitung di antara mereka, ketika kami hidup di dalam hawa nafsu daging dan menuruti kehendak daging dan pikiran kami yang jahat. Pada dasarnya kami adalah orang-orang yang harus dimurkai, sama seperti mereka yang lain. (Ef. 2:1-3).

Berdasarkan teks di atas, Paulus menunjukkan keadaan manusia berdosa yaitu: Pertama, hidup tetapi mati. Meskipun mereka secara jasmani hidup dan dapat melakukan sesuatu, namun pada dasarnya mati secara rohani karena dosa. Kedua, durhaka. Manusia berdosa hidup dalam segala macam kejahatan dan berperilaku jahat. Hidupnya dipenuhi dengan sifatsifat jahat karena dikendalikan oleh penguasa kerajaan angkasa, yaitu iblis. Ketiga, dimurkai. Akibat dari keberdosaanya, mereka hidup dalam murka Allah. Ketiga keadaan tersebut membuat manusia berdosa mustahil untuk berubah dengan sendirinya. Mereka hanya patut dihukum oleh Allah. Maka dari itu mereka perlu dilahirkan kembali agar mengalami perubahan yang radikal dalam hidupnya.

Pedidikan karakter unggul yang bertujuan untuk menghasilkan manusia yang berkarakter unggul merupakan usaha yang patut dipuji.Namun demikian usaha ini harus dibarengi dengan pemahaman manusia yang seutuhnya sebagai makhluk yang telah rusak akibat dosa. Setiap usaha yang dilakukan akan menjadi sia-sia jika tidak dilandasi dengan pemahaman tersebut. Sebelum dididik, manusia yang telah rusak harus dipulihkan lebih dahulu. Manusia itu harus berjumpa secara pribadi dengan Kristus agar mengalami kelahiran baru. Kelahiran baru akan menjadikan manusia itu sebagai ciptaan baru di dalam Kristus (I Kor. 5:17). Ciptaan baru ini akan terus menerus diperbaharui menjadi serupa dengan Kristus. Pada saat pembaharuan ini berlangsung, pendidikan karakter unggul dapat dilaksanakan secara efektif.

\section{KESIMPULAN}

Ada beberapa kesimpulan yang dapat ditarik dari pembahasan ini, yaitu: Pertama, pendidikan karakter unggul sangat dibutuhkan saat terjadi krisis karakter di tengah masyarakat akhir-akhir ini. Kedua, pendidikan karakter unggul adalah usaha sadar dan terencana dengan tujuan menginternalisasikan nilai moral dan akhlak, sehingga hal itu dapat diwujudkan dalam penerapan sikap dan perilaku yang baik. Ketiga, pendidikan karakter unggul dapat dilakukan baik secara formal melalui lembaga-lembaga pendidikan maupun secara informal, yakni di lingkungan keluarga dan masyarakat. Keempat, pendidikan karakter unggul harus diawali dengan kelahiran baru, sebab kelahiran baru merupakan titik awal perubahan yang radikal pada diri seseorang. Kelima, kelahiran baru adalah suatu peristiwa rohani di mana Allah memberikan kehidupan baru pada diri orang percaya sehingga dia menggalami persatuan dengan Kristus. Hal ini terjadi secara spiritual saat seseorang percaya kepada Yesus sebagai satu-satunya Tuhan dan Juru Selamat pribadi. Peristiwa ini menghasilkan sebuah kehidupan baru yang dinya- 
takan melalui watak yang baru dalam kehidupan sehari-hari. Keenam, pendidikan karakter unggul akan menjadi efektif jika seseorang telah mengalami ke- lahiran baru. Sebab di saat seseorang dilahirkan baru, dia akan memiliki minat-minat baru yang lebih mudah untuk diarahkan.

\section{DAFTAR RUJUKAN}

Alkitab (TB). Jakarta: Lembaga Alkitab Indonesia.

Dictionary of Pastoral Care And Counseling. 1990. Nashville: Abingdon Press.

Emiyati, Ayang. 2018. "Mendisiplin Anak Menurut Prinsip Kristen."Evangelikal: Jurnal Teologi Injili dan Pembinaan Warga Jemaat, 2 (2): 147-156.

Enns, Paul. 2003. Handbook of Theology. Malang: Literatur SAAT.

Greek New Testament (IGNT), dalam SABDA versi 4.30, 2013.

Gulo, Dali. 1982.Kamus Psikologi. Bandung: Tonis.

Guthrie, Donald. 1995. Teologi Perjanjian Baru II. Jakarta: BPK Gunung Mulia.

Hadiwijono, Harun. 1995.Iman Kristen. Jakarta: BPK Gunung Mulia.

Hartono, H.2014. "Membentuk Karakter Kristen Pada Anak Keluarga Kristen."Kurios: Jurnal Teologi dan Pendidikan Agama Kristen, 2 (1):62-69.

Kamisa. 1997. Kamus Lengkap Bahasa Indonesia. Surabaya: Kartika.

Kamus Besar Bahasa Indonesia. 1988. Jakarta: Departemen Pendidikan dan Kebudayaan.

Kesuma, Dharma. 2013. Pendidikan Karakter. Bandung: Rosida.

Kurniawan, Jimmy. 2018. "Kajian Eksegetikal tentang Kelahiran Baru Menurut Yohanes3:1-8". Gracia Deo: Jurnal Teologi, 1 (1).

Lickona, Thomas. 1991. Educating for Character: HowOur School Can Teach Respect and Responsibility. New York: Bantam Books.
Malcom, Brownlee. 2006. Pengambilan Keputus-an Etis dan Faktor-faktor di Dalamnya. Jakarta: BPK Gunung Mulia.

Milne, Bruce. 1996. Mengenali Kebenaran. Ja-karta: BPKGunung Mulia.

Mohammad, Fakhry Gaffar. 2010. "Pendidikan Karakter Berbasis Islam.” Makalah Work-shop Pendidikan Karakter Berbasis Agama.

Muslich, Masnur. 2011. Pendidikan Karakter Menjawab Tantangan Krisis Multidimensional. Jakarta: Bumi Aksara.

Rifai, E. 2012. "Pendidikan Kristen Dalam Membangun Karakter Remaja Di Sekolah Menengah". Antusias: Jurnal Teologi dan Pelayanan, 2 (2): 179-193.

Ryrie, Charles. 1999. Teologi Dasar II. Yogyakarta: Yayasan Andi.

Telaumbanua, A. 2018. "Peranan Guru Pendidikan Agama Kristen Dalam Membentuk Karakter Siswa." Jurnal Fidei: Jurnal Teologi Sistematika dan Praktika, 1 (2):219-231, http://www.stt-tawangmangu.ac.id/ejournal/index.php/fidei.

Wenas, Maria Lidya \& Darmawan, I Putu Ayub. 2017."Signifikansi Pendidikan Anak Dalam Perspektif Alkitab." Evangelikal: Jurnal Teologi Injili dan Pembinaan Warga Jemaat, 1 (2): 118-128.

Wijaya, Hengky.2016. "Pengenaan Manusia Baru Di Dalam Kristus: Natur, Proses, Dan Fakta Serta Implikasi Teologis Dan Praktisnya." Jurnal Jaffray, 14 (1). 